\title{
Pengaruh Lingkungan Kerja Dan Disiplin Kerja Terhadap Kinerja Pegawai Pada Panti Sosial Bina Grahita Belaian Kasih Jakarta Barat
}

\author{
Endang Susilowati ${ }^{1}$, Kemas Vivi Andayani ${ }^{2 *}$ \\ ${ }^{1}$ Mahasiswa Manajemen (NIM. 2016053956), Universitas Pamulang; endangsslwati208@gmail.com \\ ${ }^{2}$ Fakultas Ekonomi, Universitas Pamulang; dosen01342@unpam.ac.id*
}

Received 23 Februari 2021| Revised 23 Maret 2021 | Accepted 25 Maret 2021

*Korespondensi Penulis

\begin{abstract}
Abstrak
Penelitian ini bertujuan untuk mengetahui pengaruh lingkungan kerja dan disiplin kerja terhadap kinerja pegawai pada Panti Sosial Bina Grahita Belaian Kasih Jakarta Barat.Metode penelitian ini menggunakan metode asosiatif kuantitatif dengan teknik observasi dan kuesioner. Jumlah responden penelitian sebanyak 60 orang pegawai. Uji Analisa data yang digunakan meliputi uji validitas, uji realibilitas, uji normalitas, uji multikolionearitas, uji heterokedastisitas, uji regresi linier berganda, koefisien korelasi, koefisien determinasi, dan uji hipotesis. Hasil uji parsial diperoleh bahwa variabel lingkungan kerja tidak berpengaruh signifikan terhadap kinerja pegawai. Sedangkan disiplin kerja berpengaruh signifikan terhadap kinerja pegawai. Hasil uji simultan diperoleh hasil $\mathrm{f}_{\text {hitung }}>\mathrm{f}_{\text {tabel }}=12,012>3,16$ dengan taraf siginifikan $0,000<0,050$, artinya lingkungan kerja dan disiplin kerja terhadap kinerja pegawai berpengaruh positif dan signifikan pada Panti Sosial Bina Grahita Belaian Kasih Jakarta Barat dengan konstribusi sebesar $29,7 \%$.
\end{abstract}

Kata kunci: Lingkungan Kerja; Disiplin Kerja; Kinerja Pegawai

\begin{abstract}
This study aims to determine the effect of work environment and work discipline on employee performance at the Bina Grahita Belaian Kasih Social Institution, West Jakarta. This research method uses quantitative associative methods with observation and questionnaire techniques. The number of research respondents was 60 employees. The data analysis test used includes validity test, reliability test, normality test, multicollionearity test, heteroscedasticity test, multiple linear regression test, correlation coefficient, determination coefficient, and hypothesis testing. The partial test results show that work environment variables do not have a significant effect on employee performance. While work discipline has a significant effect on employee performance. Simultaneous test results obtained results fcount $>$ ftabel $=12.012>3.16$ with a significant level of $0.000<0.050$, meaning that the work environment and work discipline on employee performance have a positive and significant effect on the Bina Grahita Belaian Kasih Social Institution, West Jakarta with a contribution of 29.7\%.
\end{abstract}

Keywords: Work Environment; Work Discipline; Employee Performance

\section{PENDAHULUAN}

Manajemen sumber daya manusia keorganisasian yang memfokuskan diri pada unsur sumber daya manusia. Tugas manajemen sumber daya manusia adalah mengelola sumber daya manusia secara baik agar diperoleh tenaga kerja yang puas akan pekerjaannya. Menurut Bintoro dan Daryanto (2017:15) "manajemen sumber daya manusia adalah suatu ilmu atau cara bagaimana mengatur hubungan dan 
peranan sumber daya (tenaga kerja) yang dimiliki oleh individu secara efisien dan efektif serta dapat digunakan secara maksimal sehingga tercapai tujuan bersama perusahaan, karyawan dan masyarakat menjadi maksimal".

Sumber daya manusia merupakan modal utama untuk menunjukkan keberhasilan dan upaya meningkatkan daya guna dan pencapaian tujuan suatu organisasi. Hal ini sangat diperlukan karena kemajuan suatu organisasi tidak terlepas dari peranan manusia sebagai penggerak organisasi. Adapun pendapat dari Hasibuan dala R. Supomo dan Eti Nurhayati (2018:6) "sumber daya manusia adalah suatu ilmu dan seni yang mengatur hubungan dan peranan tenaga kerja agar efektif dan efisien membantu terwujudnya tujuan perusahaan, karyawan dan masyarakat".

Oleh karena itu, memahami pentingnya keberadaan sumber daya manusia di era global saat ini salah satu upaya yang harus diolah suatu perusahaan adalah dengan meningkatkan kualitas sumber daya manusia. Beberapa kegiatan pengelolaan sumber daya manusia misalnya pengadaan, penilaian, perlindungan, memotivasi karyawan, memberdayakan pegawai, peningkatan disiplin, dan bimbingan. Dengan meningkatkan kualitas sumber daya manusia diharapkan pegawai dapat meningkatkan kinerjanya. Usaha untuk meningkatkan kinerja pegawai, diantaranya dengan memperhatikan lingkungan kerja.

Lingkungan kerja sangat berpengaruh terhadap kinerja pegawai, karena lingkung-an kerja yang aman dapat mengembangkan kreativitas dan kerjasama yang baik antar pegawai serta dapat meningkatkan prestasi kerja pegawai itu sendiri sehingga perlu adanya lingkungan kerja yang baik. Lingkungan kerja yang nyaman dan menyenangkan dapat membuat mereka lebih tenang, efektif, tekun, dan serius dalam menghadapi tugas-tugasnya. Menurut Sunyoto (2015:38) "lingkungan kerja merupakan komponen yang sangat penting ketika karyawan melakukan aktivitas bekerja". Lingkungan kerja dibedakan menjadi dua yaitu lingkungan kerja fisik dan non fisik. Lingkungan kerja fisik contohnya adalah cahaya, warna, suara, dan musik, sedangkan non fisik contohnya kesejahteraan karyawan, suasana kerja, hubungan antar karyawan.

Dengan memperhatikan lingkungan kerja yang baik atau menciptakan kondisi kerja yang mampu memberikan motivasi untuk bekerja, maka akan membawa pengaruh terhadap kinerja karyawan dalam bekerja. Menurut Sri Widodo (2016:96) "lingkungan kerja merupakan lingkungan dimana para karyawan dapat melaksanakan tugasnya sehari-hari dengan keseluruhan sarana dan prasarana kerja yang diperlukan untuk melaksanakan tugastugas tersebut". Agar kinerja pegawai selalu konsisten maka setidak-tidaknya perusahaan selalu memperhatikan lingkungan dimana pegawai melaksanakan tugasnya. Para pegawai mempunyai beberapa masalah berkaitan dengan kondisi lingkungan kerja. Menurut pengamatan dalam melaksanakan penelitian ini, adapun masalah lingkungan kerja yang masih kurang baik di panti sosial bina grahita,itu terlihat dengan kurang optimalnya kebersihan di setiap sudut ruangan seperti di lantai, tangga dan area kamar anak-anak yang masih kurang bersih, mengakibatkan suhu udara diruangan tempat tersebut menjadi kurang nyaman, dan masih adanya kecemburuan antar pegawai mengenai pembagian tugas dan lain sebagainya.

Sebagaiamana dijelaskan diatas mengenai lingkungan kerja yang terjadi dipanti sosial bina grahita tersebut juga dapat mempengaruhi kinerja pegawai yang terlihat sebagai berikut:

Tabel 1. Kondisi Lingkungan Kerja Panti Sosial Bina Grahita

\begin{tabular}{|c|c|c|c|}
\hline \multirow[t]{2}{*}{ Lokasi } & \multicolumn{3}{|c|}{ Temuan Masalah } \\
\hline & Indi kator & Permasalahan & Standar Kenyamanan \\
\hline \multirow{4}{*}{$\begin{array}{l}\text { Ruangan } \\
\text { Warga } \\
\text { Binaan } \\
\text { Sosial } \\
\text { (WBS) }\end{array}$} & Kebersihan & $\begin{array}{l}\text { Kondisi pada ruang } \\
\text { tidur masih banyak } \\
\text { kotoran air kecil dan } \\
\text { air besar dan } \\
\text { beberapa bekas sisa } \\
\text { makanan atau } \\
\text { minuman warga } \\
\text { binaan sosial yang } \\
\text { memiliki kebutuhan } \\
\text { khusus. }\end{array}$ & $\begin{array}{l}\text { Pegawai yang bertugas } \\
\text { mengawasi kebersihan } \\
\text { harus lebih sigap dalam } \\
\text { menjaga kebersihan } \\
\text { ruangan, dalam sehari } 3 \\
\text { kali yaitu, pagi, siang } \\
\text { dan sore. }\end{array}$ \\
\hline & $\begin{array}{c}\text { Sirku lasi } \\
\text { Udara }\end{array}$ & $\begin{array}{l}\text { Beberapa kipas angin } \\
\text { yang masih kurang } \\
\text { berfungsi dengan } \\
\text { baik dan penyediaan } \\
\text { hexos masih belum } \\
\text { lengkap disetiap } \\
\text { ruangan membuat } \\
\text { suasana ruang masih } \\
\text { terasa pengap dan } \\
\text { panas }\end{array}$ & $\begin{array}{l}\text { Setiap ruangan harus di } \\
\text { lengkapi kipas angin dan } \\
\text { hexos harus berfungsi } \\
\text { dengan baik untuk } \\
\text { kenyamanan bersama } \\
\text { seperti warga binaan } \\
\text { sosial dan pegawai } \\
\text { panti. }\end{array}$ \\
\hline & & $\begin{array}{l}\text { Ventilasi jendela } \\
\text { banyak rusak akibat } \\
\text { ulah perilaku warga } \\
\text { binaan sosial yang } \\
\text { berkebutuhan } \\
\text { khusus. }\end{array}$ & $\begin{array}{l}\text { Jendela harus diberi } \\
\text { aling-aling besi agar } \\
\text { kaca jendela tidak sering } \\
\text { pecah karena ulah } \\
\text { perilaku warga binaan } \\
\text { sosail. Agar sirkulasi } \\
\text { udara dalam ruang } \\
\text { tetap terjaga. }\end{array}$ \\
\hline & Bau-bauan & $\begin{array}{l}\text { Masih terciumnya } \\
\text { aroma bekas air kecil } \\
\text { dan air besar warga } \\
\text { binaan sosial sering } \\
\text { tercium menyengat } \\
\text { disekitaran area } \\
\text { ruang warga binaan } \\
\text { sosial, dan banyak } \\
\text { sisa makan yang } \\
\text { berjatuhan di lantai } \\
\text { atau ditempat tidur, } \\
\text { karena cara } \\
\text { membersihkan tidak } \\
\text { baik dan maksimal. }\end{array}$ & $\begin{array}{l}\text { Pegawai harus rajin } \\
\text { dalam membersihkan } \\
\text { area aula ruang warga } \\
\text { binaan sosial, setiap } \\
\text { sudut panti, lift dan } \\
\text { tangga dan dengan } \\
\text { membersihkan lantai } \\
\text { dengan pengharum } \\
\text { lantai yang cukup } \\
\text { supaya tidak tercium } \\
\text { bau bekas kotoran } \\
\text { warga binaan sosail, } \\
\text { agar para pegawai } \\
\text { maksimal dalam }\end{array}$ \\
\hline
\end{tabular}




\begin{tabular}{|c|c|c|c|}
\hline & & $\begin{array}{l}\text { Pegawai yang } \\
\text { membina warga } \\
\text { binaan sosial tidak } \\
\text { nyaman dalam } \\
\text { memberi pengarahan } \\
\text { untuk mempebaiki } \\
\text { mental warga binaan } \\
\text { sosial. }\end{array}$ & $\begin{array}{l}\text { membina mental dan } \\
\text { fisikwarga binaan sosial. }\end{array}$ \\
\hline & Tata warna & $\begin{array}{l}\text { Dinding kamar warga } \\
\text { binaan sosial dan } \\
\text { aula cat dinding } \\
\text { kusam dan kotor. Hal } \\
\text { tersebut } \\
\text { mengganggu } \\
\text { kenyamanan warga } \\
\text { binaan sosial dan } \\
\text { pegawai karena } \\
\text { terlihat kumuh. }\end{array}$ & $\begin{array}{l}\text { Dinding kamar warga } \\
\text { binaan sosial dan aula } \\
\text { agar segera diperbaiki, } \\
\text { agar pegawai dan warga } \\
\text { binaan lebih nyaman } \\
\text { dan terlihat rapi. }\end{array}$ \\
\hline $\begin{array}{l}\text { Lingkungan } \\
\text { Panti }\end{array}$ & Keamanan & $\begin{array}{l}\text { Pengawasan yang } \\
\text { tidak ketat banyak } \\
\text { warga binaan sosial } \\
\text { mencoba untuk } \\
\text { keluar dari area } \\
\text { panti. }\end{array}$ & $\begin{array}{l}\text { Pagar, tembok } \\
\text { pembatas lingkungan } \\
\text { harus diperbaiki terlebih } \\
\text { dibagian belakang area } \\
\text { panti dan lebih } \\
\text { ditingkatkan } \\
\text { keamanannya agar } \\
\text { warga binaan sosial } \\
\text { tidak banyak yang } \\
\text { mencoba keluar. }\end{array}$ \\
\hline
\end{tabular}

Berdasarkan tabel 1 di atas, menunjukkan masih banyak kekurangan dalam kenyamanan lingkungan di panti. Ruang warga binaan sosial masih kurang baik dalam kebersihan ruangan, sirkulasi udara yang tidak baik sehingga ruangan terasa pengap karena kipas angin dan ventilasi udara yang rusak. Bau-bauan yang terasa di ruang warga binaan sosial karena banyak sisa makan warga binaan yang terjatuh ke lantai dan pegawai yang bertugas membersihkan tidak sigap sehingga lantai kotor dan bau. Dalam segi kenyamanan dan keasrian ruangan bermasalah pada dinding ruangan yang kotor dan kusam hal ini menggangu kenyamanan warga binaan sosial dan pegawa panti. Terkait pengamanan banyak warga binaan sosial yang mencoba untuk melarikan diri dari panti, pegawai keamanan harus lebih ketat dalam mengawasi warga binaan sosial agar tidak mencoba untuk melarikan diri dari panti sosial.

Salah satu faktor yang sangat berpengaruh dalam sumber daya manusia adalah faktor kedisiplinan. Kedisiplinan akan mengikuti peranan-peranan yang berlaku didalam lingkungan kerjanya dengan kesadaran diri sendiri dan tanpa ada rasa paksaan. Demikian pula pegawai yang mempunyai kedisiplinan tidak akan mencuri-curi waktu untuk melakukan hal-hal diluar pekerjaannya. Pada akhirnya kedisiplinan yang tinggi akan menghasilkan kinerja yang sangat baik karena waktu kerjanya di manfaatkan sebaik mungkin untuk melakukan pekerjaannya mencapai target yang di tentukan.

Dalam melakukan kegiatan, pegawai memerlukan petunjuk kerja dari instansi agar pelaksanaan sesuai dengan pe-rencanaan dan harus didukung dengan peraturan kerja sehingga menciptakan disiplin kerja. Pelaksanaan disiplin kerja itu sendiri harus dikelola dengan baik oleh para pegawai karena dengan kurangnya kedisiplinan para pegawai akan bekerja kurang baik, kurang maksimal dan mengakibatkan kinerja menjadi menurun. Menurut Hasibuan (2014:193) untuk memelihara dan meningkatkan kedisiplinan yang baik adalah hal yang sulit, karena banyak faktor yang mempengaruhinya.

Berdasarkan hasil pengamatan dari beberapa pegawai ternyata masih kurang baik tingkat disiplin pada pegawai, masih adanya pegawai yang melanggar peraturan terutama pada absensi, masih ada beberapa pegawai yang datang tidak tepat waktu, masih adanya pegawai yang izin pada saat jam kerja. Hal ini terjadi dikarenakan kurangnya pengawasan kerja terhadap pegawai. Oleh karena itu, di perlukan kesadaran para pegawai dalam mematuhi peraturan-peraturan yang berlaku. Betapa pentingnya faktor disiplin dalam meningkatkan kinerja pegawai dan tanpa dukungan disiplin pegawai yang baik sulit bagi instansi untuk mewujudkan tujuannya.

Dari pengamatan yang dilakukan penulis di Panti Sosial Bina Grahita ini, dimana masih terdapat pegawai yang masih kurang disiplin. Hal ini tentu dapat mengganggu berjalannya kegiatan operasional di Panti Sosial Bina Grahita. Berikut ini tabel disiplin pegawai pada Panti Sosial Bina Grahita:

Tabel 2. Kondisi Disiplin Kerja Panti Sosial Bina Grahita

\begin{tabular}{|c|c|c|}
\hline $\begin{array}{c}\text { Disiplin } \\
\text { Kerja }\end{array}$ & Temuan Kesalahan & Standar Penilaian \\
\hline \multirow{3}{*}{$\begin{array}{l}\text { Taat terhadap } \\
\text { aturan waktu }\end{array}$} & $\begin{array}{l}\text { Masih adanya pegawai yang } \\
\text { telat masuk kerja. }\end{array}$ & $\begin{array}{l}\text { Jam masuk pegawai dimulai } \\
\text { dari jam 06.30 sampai jam } \\
17.00 \text {, jadwal piket pegawai } \\
\text { dari jam } 17.00 \text { sampai jam } \\
05.00 \text { (jadwal piket sudah } \\
\text { ditentukan oleh kepala panti). }\end{array}$ \\
\hline & $\begin{array}{l}\text { Pegawai masih kurang } \\
\text { maksimal dalam memberikan } \\
\text { pelayanan kepada warga } \\
\text { binaan sosial, dan untuk } \\
\text { pembinaan sosial/mental } \\
\text { selalu lewat dari jam 07:30 } \\
\text { dan latihan fisik warga } \\
\text { binaan sosial, sehingga } \\
\text { kegiatan lainnya pun ikut } \\
\text { terganggu. }\end{array}$ & $\begin{array}{l}\text { Pembinaan sosial/ mental } \\
\text { dilaksanakan setiap hari pada } \\
\text { pukul 07:30 - 10:30, pelatihan } \\
\text { fisik seperti senam, } \\
\text { pembinaan ketrampilan, } \\
\text { pelatihan metode khusus } \\
\text { untuk warga binaan sosial } \\
\text { setiap hari dimulai pukul } \\
\text { 07:30 - 10:30. }\end{array}$ \\
\hline & $\begin{array}{l}\text { Banyak pegawai tidak masuk } \\
\text { kerja tanpa keterangan } \\
\text { apapun. }\end{array}$ & $\begin{array}{l}\text { Pegawai bila tidak masuk } \\
\text { wajib memberikan alasan } \\
\text { yang jelas, dan bila perlu } \\
\text { memberikan surat keterangan } \\
\text { sakit bila pegawai sakit. }\end{array}$ \\
\hline $\begin{array}{l}\text { Taat terhadap } \\
\text { perilaku } \\
\text { dalam } \\
\text { pekerjaan }\end{array}$ & $\begin{array}{l}\text { Pegawai sering menunjukkan } \\
\text { sikap tidak sabar dalam } \\
\text { membina dan memberi } \\
\text { pelayanan seperti } \\
\text { memandikan, memberi } \\
\text { makan, serta memberi } \\
\text { ketrampilan warga binaan } \\
\text { sosial. }\end{array}$ & $\begin{array}{l}\text { Pegawai harus sabar dan } \\
\text { bersikap lembut kepada warga } \\
\text { binaan sosial, agar warga } \\
\text { binaan sosial merasa nyaman } \\
\text { dan maksimal serta } \\
\text { berpengaruh untuk kesehatan } \\
\text { mental dan fisik warga binaan } \\
\text { sosial. }\end{array}$ \\
\hline $\begin{array}{l}\text { Taat terhadap } \\
\text { peraturan }\end{array}$ & $\begin{array}{l}\text { Pegawai tidak melaksanakan } \\
\text { tugas masing-masing sesuai }\end{array}$ & $\begin{array}{l}\text { Pegawai sudah mendapatkan } \\
\text { tugas masing-masing, pegawai }\end{array}$ \\
\hline
\end{tabular}




\begin{tabular}{lll}
\hline perusahaan/or & $\begin{array}{l}\text { yang sudah ditentukan oleh } \\
\text { ganisasi } \\
\text { pagak panti, seperti pegawai } \\
\text { tidak mebersihan sering } \\
\text { kebersihan ruananan sehingga } \\
\text { ruangan kotor dan bau } \\
\text { sehingga pegawai bagian lain } \\
\text { yang mengerjakan, hal }\end{array}$ & $\begin{array}{l}\text { melakukan pekerjaan dengan } \\
\text { baik dan disiplin agar kinerja } \\
\text { masing-masing pegawai } \\
\text { menjadi optimal. }\end{array}$ \\
& \\
& tersebut membuat \\
& kenyamanan bekerja antar & \\
pegawai kurang harmonis. & \\
& \\
Sumber: Panti Sosial Bina Grahita Belaian Kasih
\end{tabular}

Berdasarkan tabel 2 terdapat masalah pada indikator taat terhadap aturan waktu yaitu pegawai panti yang telat dalam masuk kerja, pegawai tidak tepat waktu dalam memberikan pelayanan kepada warga binaan sosial seperti pembinaan fisik dan mental, memberi makan dan memandi-kan warga binaan. Tidak memberi alasan yang jelas saat pegawai tidak masuk kerja, panti mengaharuskan pegawai yang tidak masuk kerja memberi alasan yang jelas dan memberi surat keterangan bila tidak masuk karena sakit. Perilaku yang tidak sabar dalam melayani warga binaan sosial menjadi masalah dalam disiplin perilaku karena membuat warga binaan sosial merasa tidak nyaman dan merasa tertekan.

Kondisi tersebut diatas menunjukan tren yang kurang baik, sehingga instansi/ organisasi harus segera melakukan pem-benahan, agar pegawai memiliki tingkat kedisiplinan yang tinggi. Kedisiplinan selalu berhubungan dengan sikap pegawai dalam menghargai waktu, waktu inilah yang dapat dipergunakan oleh pegawai dengan sebaik-baiknya dalam menjalankan tugas dan kewajibannya. Apabila seorang pegawai mampu menghargai waktu dengan sebaik-baiknya, maka pekerjaan yang dikerjakan dapat terselesaikan secara maksimal dan efektif. Hal ini menunjukkan bahwa masih rendahnya kesadaran pegawai terhadap pentingnya disiplin kerja serta kurang tegasnya atasan dalam pemberian sanksi pelanggaran disiplin dimana selama ini pegawai yang tidak disiplin akan diberi teguran.

Tabel 3. Kinerja Pegawai Dalam Memberi Pelayanan dan Bimbingan Fisik dan Mental Perkembangan Warga Bina Sosial Panti Sosial Bina Grahita Jakarta Barat Tahun 2017 - 2019

\begin{tabular}{|c|c|c|c|c|}
\hline \multicolumn{5}{|c|}{ TAHUN 2017} \\
\hline No & $\begin{array}{c}\text { Penyandang } \\
\text { Disabilitas }\end{array}$ & Jumlah & $\begin{array}{c}\text { Jumlah } \\
\text { Perkembangan } \\
\text { Warga Binaan }\end{array}$ & Keterangan \\
\hline 1 & Autisme & 148 & 4 & $\begin{array}{l}\text { Sudah bisa } \\
\text { merespon } \\
\text { pembicaraan } \\
\text { dan sudah bisa } \\
\text { melakukan } \\
\text { pekerjaan lain } \\
\text { diluar kebiasaan }\end{array}$ \\
\hline 2 & $\begin{array}{l}\text { Down } \\
\text { Syndrome }\end{array}$ & 5 & 2 & $\begin{array}{l}\text { Sudah mampu } \\
\text { memahami } \\
\text { kosakata, sudah } \\
\text { mandiri dalam }\end{array}$ \\
\hline
\end{tabular}

\begin{tabular}{|c|c|c|c|c|}
\hline & & & & $\begin{array}{l}\text { melakukan } \\
\text { pekerjaan, } \\
\text { makan dengan } \\
\text { baik dan benar }\end{array}$ \\
\hline 3 & $\begin{array}{l}\text { Tuna Daksa } \\
\text { (Cacat } \\
\text { Tubuh) }\end{array}$ & 42 & 28 & $\begin{array}{l}\text { tidak dapat } \\
\text { berjalan karena } \\
\text { syaraf kaki } \\
\text { bermasalah, } \\
\text { secara mental } \\
\text { sudah membaik } \\
\text { dan } 28 \text { sudah } \\
\text { dapat } \\
\text { menggunakan } \\
\text { kursi roda } \\
\text { sendiri, sisanya } \\
\text { masih sisa } \\
\text { cacat pada } \\
\text { tangan }\end{array}$ \\
\hline 4 & $\begin{array}{l}\text { Tuna Rungu } \\
\text { (Tidak } \\
\text { Dapat } \\
\text { Mendengar) } \\
\text { Dan Tuna } \\
\text { Wicara } \\
\text { (Tidak } \\
\text { Dapat } \\
\text { Bicara) }\end{array}$ & 21 & 16 & $\begin{array}{l}\text { Sudah dapat } \\
\text { berkomunikasi } \\
\text { menggunkan } \\
\text { bahasa isyarat } \\
\text { dengan baik, } \\
\text { mampu } \\
\text { menangkap } \\
\text { isyarat dan } \\
\text { ucapan dan } \\
\text { maksud orang } \\
\text { lain }\end{array}$ \\
\hline 5 & $\begin{array}{l}\text { Tuna } \\
\text { Wicara } \\
\text { (Tidak } \\
\text { Dapat } \\
\text { Bicara) }\end{array}$ & 45 & 21 & $\begin{array}{l}\text { Sudah lancar } \\
\text { menggunakan } \\
\text { bahasa isyarat } \\
\text { degan baik dan } \\
\text { sudah mampu } \\
\text { berkomunikasi } \\
\text { dengan baik }\end{array}$ \\
\hline & Total & 261 & 71 & \\
\hline \multicolumn{5}{|c|}{ TAHUN 2018} \\
\hline No & $\begin{array}{l}\text { Penyandang } \\
\text { Disabilitas }\end{array}$ & Jumlah & $\begin{array}{c}\text { Jumlah } \\
\text { Perkembanga } \\
\text { n Warga } \\
\text { Binaan } \\
\end{array}$ & Keterangan \\
\hline 1 & Autisme & 150 & 9 & $\begin{array}{l}\text { Sudah bisa } \\
\text { merespon } \\
\text { pembicaraan dan } \\
\text { sudah bisa } \\
\text { melakukan } \\
\text { pekerjaan lain } \\
\text { diluar kebiasaan, } \\
\text { sudah mampu } \\
\text { memahami } \\
\text { kegiatan sehari- } \\
\text { hari sudah bisa } \\
\text { mandiri } \\
\text { berkegiatan }\end{array}$ \\
\hline 2 & $\begin{array}{l}\text { Down } \\
\text { Syndrome }\end{array}$ & 5 & 2 & $\begin{array}{l}\text { Sudah mampu } \\
\text { memahami } \\
\text { kosata kata, } \\
\text { sudah mandiri } \\
\text { dalam melakukan } \\
\text { pekerjaan, } \\
\text { makan dengan } \\
\text { baik dan benar, } \\
\text { mampu membuat } \\
\text { keterampilan } \\
\text { kerajinan tangan }\end{array}$ \\
\hline 3 & $\begin{array}{l}\text { Tuna Daksa } \\
\text { (Cacat } \\
\text { Tubuh) }\end{array}$ & 42 & 28 & $\begin{array}{l}\text { Mampu } \\
\text { menngunakan } \\
\text { kekurangan } \\
\text { tangan untuk } \\
\text { melakukan } \\
\text { kegitan sehari- } \\
\text { hari, seperti } \\
\text { bersih-bersih } \\
\text { ruangan, } \\
\text { membuat } \\
\text { kerajinan }\end{array}$ \\
\hline 4 & $\begin{array}{l}\text { Tuna Rungu } \\
\text { (Tidak } \\
\text { Dapat } \\
\text { Mendengar) } \\
\text { Dan Tuna } \\
\text { Wicara } \\
\text { (Tidak }\end{array}$ & 21 & 16 & $\begin{array}{l}\text { Mampu } \\
\text { membaca dan } \\
\text { mengucapkan } \\
\text { dengan bahasa } \\
\text { isyarat, mampu } \\
\text { menulis dengan } \\
\text { baik }\end{array}$ \\
\hline
\end{tabular}




\begin{tabular}{|c|c|c|c|c|}
\hline & $\begin{array}{l}\text { Dapat } \\
\text { Bicara) } \\
\end{array}$ & & & \\
\hline \multirow[t]{2}{*}{5} & $\begin{array}{l}\text { Tuna } \\
\text { Wicara } \\
\text { (Tidak } \\
\text { Dapat } \\
\text { Bicara) }\end{array}$ & 45 & 21 & $\begin{array}{l}\text { Sudah lancer } \\
\text { menggunakan } \\
\text { bahasa isyarat } \\
\text { degan baik dan } \\
\text { sudah mampu } \\
\text { berkomunikasi } \\
\text { dengan baik } \\
\end{array}$ \\
\hline & Total & 263 & 76 & \\
\hline \multicolumn{5}{|c|}{ TAHUN 2019} \\
\hline No & $\begin{array}{c}\text { Penyandang } \\
\text { Disabilitas }\end{array}$ & Jumlah & $\begin{array}{c}\text { Jumlah } \\
\text { Perkembangan } \\
\text { Warga Binaan }\end{array}$ & Keterangan \\
\hline 1 & Autisme & 156 & 17 & $\begin{array}{l}\text { Sudah bisa } \\
\text { merespon } \\
\text { pembicaraan } \\
\text { dan sudah bisa } \\
\text { melakukan } \\
\text { pekerjaan lain } \\
\text { diluar kebiasaan }\end{array}$ \\
\hline 2 & $\begin{array}{l}\text { Down } \\
\text { Syndrome }\end{array}$ & 5 & 3 & $\begin{array}{l}\text { Sudah mampu } \\
\text { mengenal huruf, } \\
\text { mampu } \\
\text { mengucapakan } \\
\text { huruf dengan } \\
\text { baik, membuat } \\
\text { keterampilan }\end{array}$ \\
\hline 3 & $\begin{array}{l}\text { Tuna Daksa } \\
\text { (Cacat } \\
\text { Tubuh) }\end{array}$ & 46 & 30 & $\begin{array}{l}\text { Mampu mandiri } \\
\text { dalam } \\
\text { melakukan } \\
\text { aktifitas sehari, } \\
\text { diberi } \\
\text { keterampilan } \\
\text { mengerjakan } \\
\text { kerajinan dalam } \\
\text { keterbatasan } \\
\text { seperti tidak } \\
\text { memliki jari, atau } \\
\text { lainnya. Mampu } \\
\text { berjalan dengan } \\
\text { tertatih-tatih. }\end{array}$ \\
\hline 4 & $\begin{array}{l}\text { Tuna Rungu } \\
\text { (Tidak } \\
\text { Dapat } \\
\text { Mendengar) } \\
\text { Dan Tuna } \\
\text { Wicara } \\
\text { (Tidak } \\
\text { Dapat } \\
\text { Bicara) }\end{array}$ & 21 & 17 & $\begin{array}{l}\text { Mampu } \\
\text { membaca dan } \\
\text { mengucapkan } \\
\text { dengan bahasa } \\
\text { isyarat, mampu } \\
\text { menulis dengan } \\
\text { baik }\end{array}$ \\
\hline 5 & $\begin{array}{l}\text { Tuna } \\
\text { Wicara } \\
\text { (Tidak } \\
\text { Dapat } \\
\text { Bicara) }\end{array}$ & 52 & 24 & $\begin{array}{l}\text { Sudah lancar } \\
\text { menggunakan } \\
\text { bahasa isyarat } \\
\text { degan baik dan } \\
\text { sudah mampu } \\
\text { berkomunikasi } \\
\text { dengan baik. } \\
\end{array}$ \\
\hline & Total & 280 & 88 & \\
\hline
\end{tabular}

Pada Tabel 3 diatas dalam setiap tahunnya yang mengalami peningkatan paling sedit yaitu penyandang disabilitas autisme, sepeti tahun 2017 jumlah warga binaan penyandang disabilitas autisme berjumlah 148 dan yang mengalami perkembangan hanya 4 orang, pada tahun 2018 penyandang disabilitas autisme 150 dan mengalami perkembangan 9 orang dan 17 orang dari 156 penyandang disabilitas austime, hal ini menjadi perhatian penting pihak panti untuk meningkatkan kinerja pegawai dalam memberi pelayanan, pembinaan baik secara mental maupun fisik agar warga binaan lebih banyak yang mengalami perkembangan.

\section{Lingkungan Kerja}

Menurut Sedarmayati (2013:23) menyatakan bahwa "lingkungan kerja merupakan suatu tempat yang terdapat sejumlah kelompok dimana di dalamnya terdapat beberapa fasilitas pendukung untuk mencapai tujuan perusahaan sesuai dengan visi dan misi perusahaan". Sedangkan Siagian (2014:56) mengemuka-kan bahwa "lingkungan kerja adalah lingkungan dimana pegawai melakukan pekerjaannya sehari-hari”.

\section{Disiplin Kerja}

Menurut Handoko (2014:48) mengartikan bahwa disiplin kerja sebagai rasa sikap hormat atau mental karyawan terhadap peraturan yang dibuat dan diterapkan pada perusahaan. Sedangkan Singodimedjo dalam Edy Sutrisno (2016:89) mengemukakan bahwa "disiplin kerjaadalah perilaku seseorang yang sesuai dengan peraturan, prosedur kerja yang ada atau disiplin adalah sikap, tingkah laku, dan perbuatan yang sesuai dengan peraturan dari organisasi baik tertulis maupun tidak tertulis'.

\section{Kinerja}

Menurut Anwar Prabu Mangku-negara (2016:67) "kinerja adalah hasil kerja secara kualitas dan kuantitas yang dicapai oleh seseorang pegawai dalam melaksana-kan tugasnya sesuai dengan tanggung jawab yang diberikan kepadanya". Menurut Edison (2016:190) "kinerja adalah hasil dari suatu proses yang mengacu dan diukur selama periode waktu tertentu berdasarkan ketentuan dan kesepakatan yang telah ditetapkan sebelumnya". Sedangkan menurut Hasibuan (2017:94) "kinerja adalah suatu hasil kerja yang dicapai seseorang dalam melaksanakan tugastugas yang dibebankan kepadanya yang didasarkan atas kecakapan, pengalaman, dan kesungguhan serta waktu".

\section{Penelitian Terdahuluan}

Penelitian Mohammad Amir Fiqi (2018) tentang "Pengaruh Lingkungan Kerja dan Disiplin Kerja Terhadap Kinerja Karyawan pada CV Tiara Abadi Pamekasan". Hasil penelitian menunjukkan bahwa bahwa variabel independen lingkungan kerja (X1) dan disiplin kerja (X2) secara simultan berpengaruh signifikan terhadap variabel kinerja karyawan (Y).

Hasil penelitian Apfia Ferawati (2017) tentang "Pengaruh Lingkungan Kerja dan 
Disiplin Kerja Terhadap Kinerja Karyawan PT. Cahaya Indo Persada Surabaya" menunjukkan bahwa lingkungan kerja dan disiplin kerja mempunyai pengaruh signifikan terhadap kinerja karyawan.

Hasil Penelitian Aini Kusniawati, Nurhayati., Rosy Herlina tentang "Pengaruh Lingkungan Kerja dan Disiplin Kerja Terhadap Kinerja Karyawan pada PT Gapuraning Rahayu Ciamis" bahwa lingkungan kerja dan disiplin kerja berpengaruh terhadap kinerja karyawan.

\section{Kerangka Berpikir}

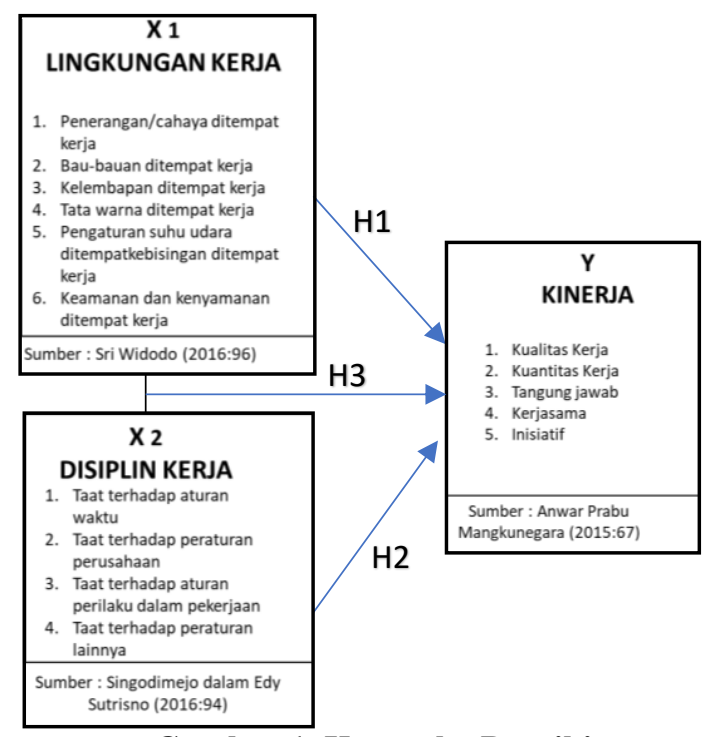

Gambar 1 .Kerangka Berpikir

\section{Hipotesis}

Hipotesis yang akan dibuktikan dalam penelitian ini adalah :

$\mathrm{H} 1=$ Diduga ada pengaruh lingkungan kerja (X1) terhadap kinerja (Y) pegawai pada Panti Sosial Bina Grahita Jakarta Barat.

$\mathrm{H} 2=$ Diduga ada pengaruh disiplin kerja $(\mathrm{X} 2)$ terhadap kinerja (Y) pegawai pada Panti Sosial Bina Grahita Jakarta Barat.

H3= Diduga ada pengaruh lingkungan kerja (X1) dan disiplin kerja (X2) terhadap kinerja (Y) pegawai pada Panti Sosial Bina Grahita Jakarta Barat secara simultan.

\section{METODE}

Jenis penelitian dalam penelitian ini yaitu penelitian Definisi metode penelitian asosiatif menurut Sugiyono (2015: 11) yaitu "penelitian asosiatif bertujuan untuk mengetahui pengaruh ataupun juga hubungan antara dua variabel atau lebih". Penelitian ini untung mengetahui pengaruh lingkungan kerja dan disiplin kerja terhdapat kinerja pegawai pada Panti Sosial Bina Grahita Jakarta Barat, dengan ini 3 variabel penelitian yang diketahui pengaruhnya. Sedangkan metode yang digunakan dalam penelitian ini menggunakan metode kuantitatif. Dalam penelitian ini sampel yang diambil adalah semua pegawai pada Panti Sosial Bina Grahita Belaian Kasih Jakarta Barat sebanyak 60 orang responden yang disebut dengan sampel jenuh.

\section{HASIL DAN PEMBAHASAN}

\section{Uji Normalitas}

Uji normalitas bertujuan untuk menguji apakah dalam model regresi, variabel dependen dan variabel independen berdistribusi normal atau berdistribusi tidak normal. Model regresi yang baik adalah distribusi data normal atau mendekati normal. Uji normalitas dilakukan untuk memastikan asusmi bahwa persamaan tersebut berdistribusi normal. Pengujian ini dilakukan dengan mengamati histogram atas nilai residual dan grafik normal probability plot. Deteksi pengambilan keputusan adalah dengan syarat penyebaran titik-titik residual mengikuti arah garis diagonal.

Adapun hasil uji normalitas yang diolah dengan SPSS versi 24 adalah sebagai berikut:

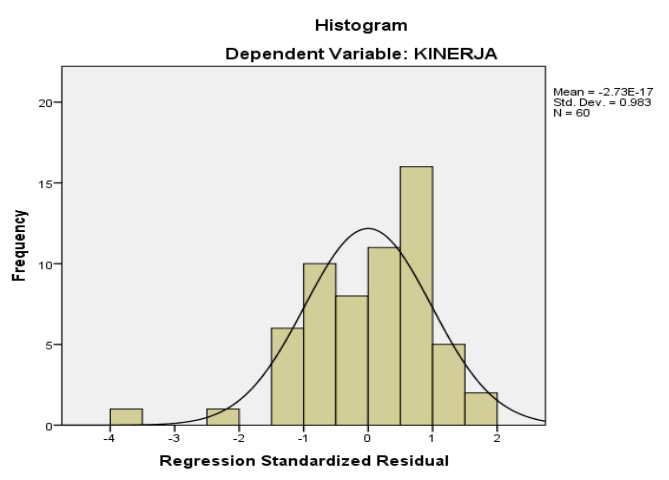

Gambar 2. Hasil Uji Normal Histogram

Sumber: Data diperoleh dari SPSS versi 24

Dalam penelitian ini terdapat cara untuk mendeteksi apakah residual berdistribusi normal atau tidak yaitu dengan menggunakan grafik normal P-Plot. Kemudian dilakukan pengujian linieritas, untuk mengetahui apakah terdapat hubungan linier antara variabel independent dan dependent. Dari hasil pengolahan data maka diperoleh grafik normal p-p plot of Regression Strandarized Residual untuk dependent variabel kinerja pegawai. 


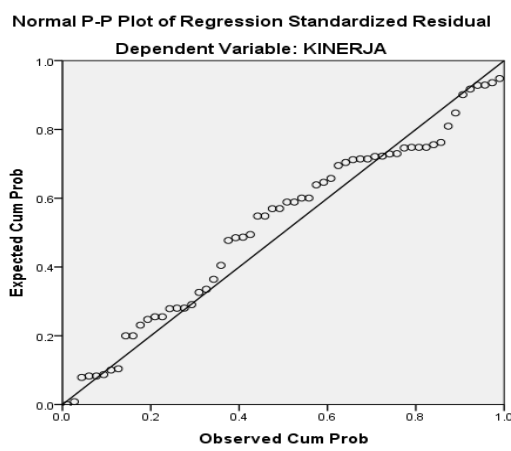

Gambar 3. Hasil Uji Normal P-Plot

Sumber: Data diperoleh dari SPSS versi 24

Jika dilihat berdasarkan gambar 3 di atas normal probability plot menghasilkan data berdistribusi normal. Dapat dilihat bahwa titiktitik menyebar dan mendekati garis diagonal sehingga dapat disimpulkan bahwa model regresi memenuhi asumsi normalitas.

\section{Uji Multikoliniearitas}

Multikolinearitas berarti adanya hubungan linear yang sempurna atau pasti. Uji ini digunakan untuk melihat ada tidaknya korelasi yang tinggi antara variabel lingkungan kerja dan disiplin kerja dalam suatu regresi berganda. Cara umum yang digunakan dalam uji multikolinearitas oleh peneliti untuk mendeteksi ada tidaknya masalah multikolinearitas pada model regresi dengan melihat nilai Tolerance dan VIF (Variance Inflation Factor). Nilai yang direkomendasikan untuk menunjukkan tidak adanya masalah multikolinearitas adalah nilai Tolerance harus diatas dari 0,10 dan Variance Inflation Factor (VIF) harus dibawah dari 10. Hasil penelitian dari uji multikolinearitas adalah sebagai berikut:

Tabel 4. Hasil Uji Multikolinearitas Coefficients $^{\mathrm{a}}$

\begin{tabular}{|c|c|c|}
\hline \multirow[b]{2}{*}{ Model } & \multicolumn{2}{|c|}{ Collinearity Statistics } \\
\hline & Tolerance & VIF \\
\hline 1 (Constant) & & \\
\hline $\begin{array}{l}\text { Lingkungan } \\
\text { Kerja }\left(\mathrm{X}_{1}\right)\end{array}$ & .899 & 1.112 \\
\hline $\begin{array}{l}\text { Disiplin Kerja } \\
\left(\mathrm{X}_{2}\right)\end{array}$ & .899 & 1.112 \\
\hline
\end{tabular}

a. Dependent Variable: Kinerja (Y)

Sumber: Data diolah dari SPSS versi 24

Dari tabel di atas hasil uji multikoliniearitas menunjukkan bahwa semua variabel bebas mempunyai nilai VIF lebih kecil dari 10 (VIF < 10) dan nilai tolerance lebih besar dari 0,10 (tolerance> 0,10), maka dapat disimpulkan bahwa variabel independent terbebas dari asusmsi multikoliniearitas.

\section{Uji Heterokedastisitas}

Uji heterokedastisitas bertujuan untuk menguji apakah dalam model regresi terjadi ketidaksamaan varian dari residual satu pengamatan ke pengamatan yang lain. Asumsi heterokedastisitas adalah asumsi dalam regresi dimana varians dari residual tidak sama untuk suatu pengamatan ke pengamatan lain. Heterokedastisitas dapat dideteksi dengan beberapa macam cara, antara lain dengan menggunakan uji scatterplot. Dalam uji scatterplot, cara mendeteksinya adalah dengan melihat ada tidaknya pola tertentu pada grafik scatterplot antara SRESID dan ZPRED. Berikut ini adalah hasil uji heterokedastisitas dengan menggunakan scatterplot.

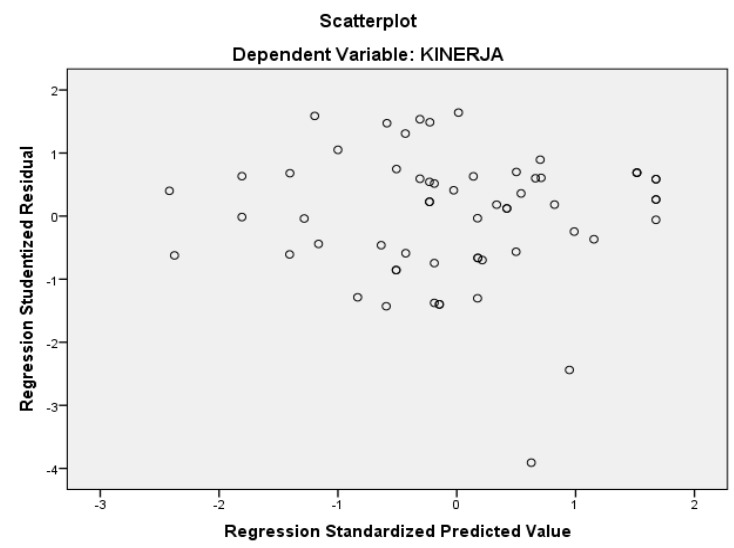

Gambar 4. Hasil Uji Heterokedastisitas Sumber: Data diolah dari SPSS versi 24

Dari grafik scatterplot diatas dapat dilihat bahwa tidak ada pola tertentu karena titik menyebar tidak beraturan diatas dan dibawah sumbu 0 pada sumbu Y dan tidak membentuk sebuah pola yang jelas. Maka dapat disimpulkan bahwa tidak terdapat gejala heterokedastisitas dalam penelitian ini.

\section{Uji Analisis Regresi Sederhana}

Analisis regresi linier sederhana adalah hubungan antara linier satu variabel independen yaitu lingkungan kerja $\left(\mathrm{X}_{1}\right)$ dan disiplin kerja $\left(\mathrm{X}_{2}\right)$ dengan variabel dependen kinerja $(\mathrm{Y})$. Analisis ini untuk mengetahui arah hubungan antara variabel independen dengan variabel dependen apakah positif atau negatif untuk memprediksi nilai variabel independen mengalami kenaikan atau penurunan. 
Tabel 5. Hasil Uji Analisis Regresi Sederhana Variabel Lingkungan Kerja Terhadap Kinerja Coefficients $^{\mathrm{a}}$

\begin{tabular}{|c|c|c|c|c|c|c|}
\hline & & \multicolumn{2}{|c|}{$\begin{array}{c}\text { Unstandardized } \\
\text { Coefficients }\end{array}$} & $\begin{array}{l}\text { Standardized } \\
\text { Coefficients } \\
\end{array}$ & \multirow[b]{2}{*}{$\mathrm{t}$} & \multirow[b]{2}{*}{ Sig. } \\
\hline \multicolumn{2}{|c|}{ Model } & $\mathrm{B}$ & $\begin{array}{l}\text { Std. } \\
\text { Error }\end{array}$ & Beta & & \\
\hline \multirow[t]{2}{*}{1} & (Constant) & 33.557 & 3.242 & & 10.352 & .000 \\
\hline & $\begin{array}{l}\text { Lingkungan } \\
\text { kerja }\end{array}$ & .183 & .082 & .282 & 2.243 & .029 \\
\hline
\end{tabular}

Hasil perhitungan regresi pada tabel di atas, diperoleh persamaan regresi $\mathbf{Y}=\mathbf{3 3 , 5 5 7 +}$ $\mathbf{0 , 1 8 3} \mathbf{X}_{1 .}$

a. Nilai konstanta sebesar 33,557 artinya apabila variabel lingkungan kerja sama dengan nol maka variabel kinerja bernilai sebesar 33,557.

b. Nilai koefisien lingkungan kerja $\left(\mathrm{X}_{1}\right)$ sebesar 0,183 dapat diartikan apabila konstanta tetap dan tidak ada perubahan pada variabel disiplin kerja $\left(\mathrm{X}_{2}\right)$, maka setiap perubahan 1 unit pada variabel lingkungan kerja akan mengakibatkan terjadinya perubahan pada kinerja (Y) sebesar 0,183.

Tabel 6. Hasil Uji Analisis Regresi Sederhana Variabel Disiplin Kerja Terhadap Kinerja Coefficients $^{\mathrm{a}}$

\begin{tabular}{|c|c|c|c|c|c|c|}
\hline \multirow{2}{*}{\multicolumn{2}{|c|}{ Model }} & \multicolumn{2}{|c|}{$\begin{array}{l}\text { Unstandardized } \\
\text { Coefficients }\end{array}$} & \multirow{2}{*}{$\begin{array}{c}\begin{array}{c}\text { Standardized } \\
\text { Coefficients }\end{array} \\
\text { Beta }\end{array}$} & \multirow[b]{2}{*}{$\mathrm{t}$} & \multirow[b]{2}{*}{ Sig. } \\
\hline & & B & $\begin{array}{c}\text { Std. } \\
\text { Error }\end{array}$ & & & \\
\hline \multirow[t]{2}{*}{1} & (Constant) & 23.353 & 3.668 & & 6.366 & .000 \\
\hline & $\begin{array}{l}\text { Lingkungan } \\
\text { kerja }\end{array}$ & .540 & .113 & .531 & 4.774 & .000 \\
\hline
\end{tabular}

Sumber : Data diolah dari SPSS versi 24

Hasil perhitungan regresi pada tabel di atas, diperoleh persamaan regresi $\mathrm{Y}=23,353+$ $0,540 \times 2$.

a. Nilai konstanta sebesar 23,353 artinya apabila variabel disiplin kerja sama dengan nol maka variabel kinerja bernilai sebesar 23,353.

b. Nilai koefisien disiplin kerja (X2) sebesar 0,540 dapat diartikan apabila konstanta tetap dan tidak ada perubahan pada variabel lingkungan kerja (X1), maka setiap perubahan 1 unit pada variabel disiplin kerja akan mengakibatkan terjadinya perubahan pada kinerja (Y) sebesar 0,540 .

\section{Uji Analisis Regresi Berganda}

Analisis regresi berganda adalah hubungan secara linier antara dua atau lebih variabel independent (X1 dan X2) dengan variabel dependent (Y). Analisis ini untuk mengetahui arah hubungan antara variabel dependen apakah masing-masing variabel independent berhubungan posistif atau negatif dan untuk memprediksi nilai dari variabel dependen apabila nilai independen mengalami kenaikan atau penrunan. Data yang digunakan biasanya berskala interval atau rasio. Untuk mengetahui ada tidaknya pengaruh antara dua variabel independen terhadap variabel dependen dapat dilihat dalam tabel berikut :

Tabel 6. Hasil Uji Analisis Regresi Berganda

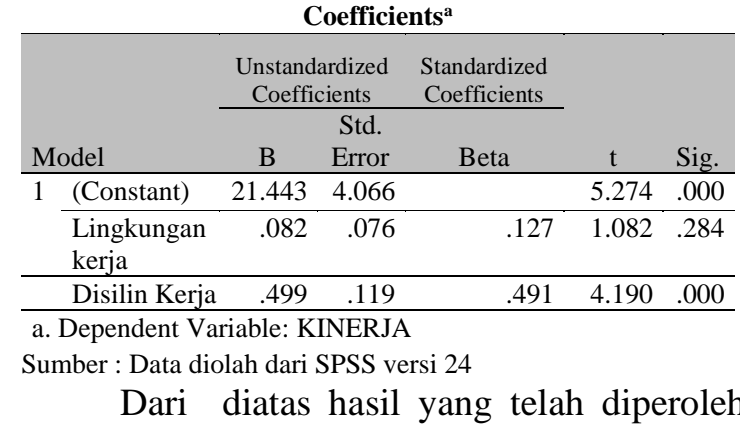
persamaan regresi $\mathbf{Y}=\mathbf{2 1 . 4 3 3}+\mathbf{0 , 0 8 2} \mathbf{X}_{\mathbf{1}}+$ $\mathbf{0 , 4 9 9} \mathrm{X}_{2}$. Model tersebut dapat diintepretasikan sebagai berikut:

a. Nilai konstanta sebesar 21,433 artinya apabila variabel independennya sama dengan nol maka variabel kinerja pegawai bernilai sebesar 21,433.

b. Nilai koefisien lingkungan kerja sebesar 0,082 dapat diartikan bahwa setiap penambahan 1 satuan, maka lingkungan kerja akan naik sebesar 0,082 satuan jika variabel lain tetap.

c. Nilai koefisien disiplin kerja sebesar 0,499 dapat diartikan bahwa setiap penambahan 1 satuan, maka disiplin kerja akan naik sebesar 0,499 satuan jika variabel lain tetap.

\section{Uji Koefisien Korelasi (R)}

Analisis korelasi digunakan untuk mencari hubungan antara dua variabel bebas atau lebih secara bersama-sama dihubungkan dengan variabel terikatnya. Sehingga dapat diketahui besarannya sumbangan seluruh variabel bebas yang menjadi objek penelitian terhadap variabel terikatnya.

Tabel 8. Hasil Uji Korelasi Lingkungan Kerja (X1) Terhadap Kinerja (Y) Model Summary ${ }^{\mathrm{b}}$

\begin{tabular}{|c|c|c|c|c|}
\hline Model & $\mathrm{R}$ & R Square & $\begin{array}{l}\text { Adjusted R } \\
\text { Square }\end{array}$ & $\begin{array}{l}\text { Std. Error of the } \\
\text { Estimate }\end{array}$ \\
\hline 1 & $.282^{\mathrm{a}}$ & .080 & .064 & 3.640 \\
\hline $\begin{array}{l}\text { a. Predi } \\
\text { b. Depe } \\
\text { Sumbe }\end{array}$ & $\begin{array}{l}\text { tors: (C } \\
\text { dent V } \\
\text { : Dat }\end{array}$ & $\begin{array}{l}\text { Constant), I } \\
\text { Variable: K } \\
\text { a diolah d }\end{array}$ & $\begin{array}{l}\text { INGKUNGAI } \\
\text { NERJA } \\
\text { ri SPSS vers }\end{array}$ & $\begin{array}{l}\text { KERJA } \\
24\end{array}$ \\
\hline
\end{tabular}


Hasil ji koefisien korelasi diperoleh nilai $\mathrm{R}$ sebesar 0,282 . Hal ini menunjukkan bahwa korelasi atau hubungan antara kinerja dengan lingkungan kerja mempunyai tingkat hubungan yang rendah.

Tabel 9. Uji Korelasi Disiplin Kerja (X2) Terhadap Kinerja (Y) Model Summary ${ }^{\mathrm{b}}$

\begin{tabular}{lcrcr} 
Model & R & R Square & $\begin{array}{c}\text { Adjusted R } \\
\text { Square }\end{array}$ & $\begin{array}{c}\text { Std. Error of the } \\
\text { Estimate }\end{array}$ \\
\hline 1 & $.531^{\mathrm{a}}$ & .282 & .270 & 3.215 \\
\hline
\end{tabular}

a. Predictors: (Constant), DISIPLIN KERJA

b. Dependent Variable: KINERJA

Sumber : Data diolah dari SPSS versi 24

Hasil dari uji koefisien korelasi diperoleh nilai $\mathrm{R}$ sebesar 0,531 . Hal ini menunjukkan bahwa korelasi atau hubungan antara kinerja dengan disiplin kerja mempunyai tingkat hubungan yang sedang.

Tabel 10. Hasil Uji Koefisien Korelasi Model Summary $^{\mathrm{b}}$

\begin{tabular}{lcccc}
\multicolumn{5}{c}{ Model Summary $^{\mathbf{b}}$} \\
\begin{tabular}{lcccc} 
Model & R & R Square & $\begin{array}{c}\text { Adjusted R } \\
\text { Square }\end{array}$ & $\begin{array}{c}\text { Std. Error of the } \\
\text { Estimate }\end{array}$ \\
\hline 1 & $.545^{\text {a }}$ & .297 & .272 & 3.211 \\
\hline a. Predictors: (Constant), Lingkungan Kerja , Disiplin Kerja \\
b. Dependent Variable: KINERJA
\end{tabular}
\end{tabular}

Sumber: Data diolah dari SPSS versi 24

Hasil dari uji koefisien korelasi diperoleh nilai $\mathrm{R}$ sebesar 0,545 . Hal ini menunjukkan bahwa korelasi atau hubungan antara kinerja pegawai dengan lingkungan kerja dan disiplin kerja mempunyai tingkat hubungan yang sedang.

\section{Uji Koefisiensi Determinasi $\left(\mathbf{R}^{\mathbf{2}}\right)$}

Uji koefisien determinasi digunakan untuk mengetahui sebesar mana hubungan antara lingkungan kerja $\left(\mathrm{X}_{1}\right)$ dan disiplin kerja $\left(\mathrm{X}_{2}\right)$ terhadap kinerja pegawai karyawan $(\mathrm{Y})$. Hasil analisis uji koefisien determinasi dapat dilihat pada tabel berikut ini:

Tabel 11. Hasil Uji Koefisien Determinasi Model Summary

\begin{tabular}{lcccc}
\hline Model & $\mathrm{R}$ & $\mathrm{R}$ Square & $\begin{array}{c}\text { Adjusted R } \\
\text { Square }\end{array}$ & $\begin{array}{c}\text { Std. Error of the } \\
\text { Estimate }\end{array}$ \\
\hline 1 & $.545^{\text {a }}$ & .297 & .272 & 3.211 \\
\hline a. Predictors: (Constant), Lingkungan Kerja , Disiplin Kerja \\
b. Dependent Variable: KINERJA \\
Sumber: Data diolah dari SPSS versi 24
\end{tabular}

Berdasarkan tabel diperoleh besarnya $\mathrm{R}$ square adalah 0,297 atau 29,7\%. Hal ini menunjukan bahwa persentase pengaruh variabel independen lingkungan kerja dan disiplin kerja terhadap dependen kinerja pegawai sebesar $29,7 \%$ sedangkan sisanya $(100 \%-29,7 \%=70,3 \%)$ dipengaruhi atau dijelaskan oleh variabel lain diluar variabel yang diteliti.

\section{Uji Parsial (uji t)}

Uji parsial (uji t) bertujuan untuk menunjukan seberapa jauh pengaruh satu variabel independen secara individual dalam menerangkan variasi variabel dependen atau untuk menguji variabel bebas secara parsial (individu).

\begin{tabular}{lrrrrrr}
\multicolumn{7}{c}{ Tabel 12. Hasil Uji t } \\
Coefficients
\end{tabular}

Sumber : Data diolah dari SPSS versi 24

Berdasarkan tabel di atas diperoleh hasil:

Variabel lingkungan kerja mempunyai tingkat signifikasi sebesar 0,284 nilai ini lebih besar dari $0,05(0,284>0,05)$ dengan nilai thitung $1,082<2,002$. Hal ini berarti $\mathrm{H}_{1}$ ditolak. Sehingga dapat dikatakan bahwa lingkungan kerja berpengaruh positif namun tidak signifikan terhadap kinerja pegawai.

Variabel disiplin kerja mempunyai tingkat signifikasi sebesar 0.000 nilai ini lebih kecil dari $0,05(0,000<0,05)$ dengan nilai $\mathrm{t}$ hitung 4,190>2,002. Hal ini berarti $\mathrm{H}_{2}$ diterima. Sehingga dapat dikatakan bahwa disiplin kerja berpengaruh signifikan terhadap kinerja pegawai.

\section{Uji Simultan (F)}

Uji simultan (F) bertujuan untuk menunjukan apakah semua variabel bebas atau independen yang dimasukkan dalam model regresi mempunyai pengaruh yang signifikan secara bersama-sama terhadap variabel terikat atau dependen.

Tabel 13. Hasil Uji Simultan (F)

\begin{tabular}{llrrrrr}
\multicolumn{8}{c}{ ANOVA $^{\mathbf{a}}$} \\
Model & $\begin{array}{c}\text { Sum of } \\
\text { Squares }\end{array}$ & \multicolumn{1}{c}{ df } & $\begin{array}{c}\text { Mean } \\
\text { Square }\end{array}$ & F & Sig. \\
\hline 1 & Regression & 247.658 & 2 & 123.829 & 12.012 & $.000^{\mathrm{b}}$ \\
\cline { 2 - 7 } & Residual & 587.592 & 57 & 10.309 & & \\
\cline { 2 - 7 } & Total & 835.250 & 59 & & & \\
\hline
\end{tabular}

a. Dependent Variable: KINERJA

b. Predictors: (Constant), DISIPLIN KERJA, LINGKUNGAN KERJA

Sumber: Hasil diperoleh dari SPSS versi 24

Dari tabel diatas diperoleh nilai F-hitung sebesar $12,012>$ F-tabel $(3,16)$ dengan nilai signifikan $0,000<0,05$. Hal ini menunjukkan bahwa lingkungan kerja dan disiplin kerja secara simultan mempunyai pengaruh yang signifikan terhadap kinerja pegawai. 


\section{Pembahasan}

Hasil uji parsial pengaruh lingkungan kerja terhadap kinerja diperoleh nilai signifikan $0,284>0,05)$ dengan nilai t-hitung 1,082 < 2,002 artinya lingkungan kerja tidak berpengaruh signifikan terhadap kinerja pegawai. Hasil pengujian hipotesa yang dilakukan mendukung penelitian sebelumnya mengenai pengaruh lingkungan kerja terhadap kinerja karyawan yaitu Sudarmin Manik (2018).

Hasil uji parsial pengaruh disiplin kerja terhadap kinerja diperoleh nilai signifikansi $0,000<0,05)$ dengan nilai t-hitung 4,190> 2,002 artinya disiplin kerja berpengaruh signifikan terhadap kinerja pegawai. Hasil pengujian hipotesa yang dilakukan mendukung penelitian sebelumnya mengenai pengaruh disiplin kerja terhadap kinerja karyawan yaitu Astadi Pangarso (2016).

Hasil uji secara simultan untuk pengaruh variabel lingkungan kerja dan disiplin kerja terhadap kinerja diperoleh nilai $\mathrm{F}$ tabel sebesar $12,012>3,16$ dengan nilai signifikan $0,000<$ 0,05 . Artinya lingkungan kerja dan disiplin kerja secara simultan mempunyai pengaruh yang signifikan terhadap kinerja pegawai. Hasil pengujian hipotesa yang dilakukan mendukung penelitian sebelumnya mengenai pengaruh lingkungan kerja dan disiplin kerja terhadap kinerja karyawan yaitu Fridayana Yudiaatmaja (2016)

\section{SIMPULAN}

Kesimpulan yang diperoleh dari hasil penelitian ini antara lain:

Tidak terdapat pengaruh positif dan signifikan lingkungan kerja terhadap kinerja pegawai ditujukan dengan signifikansi 0,284 > 0,05 dan nilai t-hitung $1,082<2,002$.

Terdapat pengaruh positif dan signifikan disiplin kerja terhadap kinerja pegawai ditujukan dengan signifikansi $0,000<0,05$ dan nilai t-hitung 4,190 > 2,002.

Secara simultan terdapat pengaruh positif dan signifikan lingkungan kerja dan disiplin kerja terhadap kinerja pegawai dengan nilai $\mathrm{F}$ tabel 12,012>3,16 dan nilai signifikan 0,000 < 0,050 .

\section{DAFTAR PUSTAKA}

Afandi, P. (2016). Concept \& Indicator Human Resources Management for Management Research. Yogyakarta: Deepublish.

Algifari. (2010). Statistika Deskriptif Plus untuk Ekonomi dan Bisnis. Yogyakarta: Sekolah Tinggi Ilmu Manajemen YKPN.

Andi Supangat. (2015). Statistik Dalam Kajian Deskriptif, Inferensi, dan Nonparametrik. Jakarta: Kencana Prenada Media Group.

Arief, M. Rudyanto. (2011). Pemrograman Web Dinamis Menggunakan PHP dan MYSQL. Yogyakarta: C.V. Andi Offest.

Bintoro \& Daryanto. (2017). Manajemen Penilaian Kinerja Karyawan. Cetakan1.Yogyakarta: Gava Media.

Edison, Emron. (2016). Manajemen Sumber Daya Manusia. Bandung: Alfabeta.

Erni, \& Kurniawan. (2017). Pengantar Manajamen, edisi 1. Jakarta: Kencana.

Ghozali, Imam. (2013). Aplikasi Analisis Multivariat dengan Program IBM SPSS. Edisi 7. Semarang: Universitas Diponegoro.

Handoko, T. Hani. (2014). Manajemen Personalia dan Sumber Daya Manusia. Yogyakarta: BPFE.

Harahap, Sofyan Syafri. (2013). Analisa Kritis atas Laporan Keuangan. Jakarta: PT Raja Grafindo Persada.

Hasibuan, Malayu S.P. (2014). Manajemen Sumber Daya Manusia. Jakarta: Bumi Aksara.

. (2016). Manajemen Sumber Daya Manusia. Edisi Revisi. Jakarta: PT Bumi Aksara.

(2017). Manajemen Sumber Daya Manusia. Edisi Revisi. Jakarta: Bumi Aksara.

(2018). Manajemen Sumber Daya Manusia. Edisi Revisi. Jakarta: PT. Bumi Aksara.

Ismainar, Hetty. (2015). Manajemen Unit Kerja. Yogyakarta: Deepublish.

Mangkunegara, A.A, Anwar Prabu. (2013). Manajemen Sumber Daya Manusia Perusahaan. Bandung: Remaja Rosda karya.

(2015). Manajemen Sumber Daya Manusia Perusahaan. Bandung: Remaja Rosda karya.

(2016). Manajemen Sumber Daya Manusia Perusahaan. Bandung: Remaja Rosda karya. 
Nurhayati Eti \& R.Supomo. (2018). Manajemen Sumber Daya Manusia. Bandung: Yrama Widya.

Rivai, Veithzal, (2012). Manajemen Sumber Daya Manusia untuk Perusahaan: dari Teori Ke Praktik, Edisi Pertama. Jakarta: Penerbit PT. Raja Grafindo Persada.

Sedarmayanti. (2013). Manajemen Sumber Daya Manusia. Bandung: Refika Aditama.

. (2015). Manajemen Sumber Daya Manusia. Bandung: Refika Aditama.

Singodimedjo, Markum. (2016). Manajemen Sumber Daya Manusia. Surabaya: SMMAS.

Sondang P. Siagian. (2014). Manajemen Sumber Daya Manusia. Jakarta: Bumi Aksara.

Sugiyono. (2015). Metode Penelitian Kuantitatif, Kualitatif dan $R \& D$. Bandung: PT Alfabet.

. (2016). Metode Penelitian Kuantitatif, Kualitatif dan $R \& D$. Bandung: PT Alfabet.

. (2017). Metode Penelitian Kuantitatif, Kualitatif dan $R \& D$. Bandung:

PT Alfabet.

Sunyoto, Danang. (2015). Manajemen dan Pengembangan Sumber Daya Manusia (Cetakan Pertama). Yogyakarta: CAPS (Center for Academic Publishing Service).

Sutrisno, Edy. (2014). Manajemen Sumber Daya Manusia. Cetak Ke Enam. Jakarta: Pranada Media Group.

- (2016). Manajemen Sumber Daya Manusia. Cetakan ke-8. Jakarta: Prenada Media Group.

Widodo, S. E. (2015). Manajemen Pengembangan Sumber Daya Manusia. Yogyakarta: Pustaka Pelajar. - (2016). Manajemen Sumber Daya Manusia: Teori, Perencanaan

Strategi, Isu-isu Utama dan Globalisasi. Bandung: Manggu Media. 